\title{
EFFECT OF ABATTOIR WASTE ON THE PHYSICOCHEMICAL AND BACTERIOLOGICAL QUALITIES OF NEW-ARTISAN RIVER IN ENUGU, NIGERIA
}

\author{
C. N. Eze ${ }^{1}$ and P. C. Eze ${ }^{2, *}$ \\ 1, 2, Dept. of Agric. AND Bioresources Engr. EnUgu State Univ. of SCI. \& TeCh., ENUGU STATE. NIGERIA \\ Email addresses:1 nkechi.eze@esut.edu.ng, ${ }^{2}$ paul.eze@esut.edu.ng
}

\begin{abstract}
The effects of abattoir wastewater pollution at New Artisan River in New Artisan, Enugu East, Enugu State of Nigeria were investigated. The study involved the collection of water samples at the designated points from the New Artisan River where the abattoir wastewaters are discharged. The physical, chemical and bacteriological analyses of the wastewater samples were conducted using standard analytical methods. Results of the laboratory tests were analyzed using statistical tests. The results obtained were compared with World Health Organization (WHO) and other international standards. The results obtained were $\mathrm{pH} ; 6.54$ at $25.0^{\circ} \mathrm{C}$, biochemical oxygen demand (BOD); 5009 (mg/L), chemical oxygen demand (COD); 3820(mg/L), total suspended solids (TSS); $97.3(\mathrm{mg} / \mathrm{L})$, total dissolved solids (TDS); $56.7(\mathrm{mg} / \mathrm{L})$, conductivity; $113(\mu \mathrm{S} / \mathrm{cm})$, , dissolved oxygen (DO); 8.60(mg/L), turbidity; 24.0(NTU), colour; 117(Pt-Co), total solids (TS); 154(mg/L), total hardness (TH); 42.0(mg/L), calcium; $10.4(\mathrm{mg} / \mathrm{L})$, coliforms; $9000(\mathrm{cfu} / \mathrm{ml})$ and E-coli; $7500(\mathrm{cfu} / \mathrm{ml})$. Analyses of the results showed that the samples were highly polluted. Hence, appropriate measures are herein suggested as a means to control pollution discharge in New-Artisan River in order to enhance the quality of human and aquatic life
\end{abstract}

Keywords: Abattoir, wastewater, river, pollution, drinking water.

\section{INTRODUCTION}

Water quality is a growing concern throughout the developing world. Drinking water sources are under increasing threat from contamination, with farreaching consequences for the health of people and for the economic and social development of communities and nations. Deteriorating water quality also threatens the Sustainable Development Goals (SDGs) water target of having the proportion of people without sustainable access to safe water. Freshwater availability and water use have been recognized as global issues, and their consistent quantification is required to provide an integrated view of water situation on earth, [12].

The Chemical contamination of water supplies both naturally occurring and from pollution is a very serious problem. But more serious still is the microbiological contamination of drinking water supplies, especially from faeces. Faecal contamination of drinking water is a major contributor to diarrheal and cholera diseases, which kill millions of children every year. As populations, pollution and environmental degradation increases, so will the chemical and microbiological contamination of the water supplies. This is due to a variety of factors, including population pressure, urbanization and the inadequate construction, operation and maintenance of water systems, [4]. Pollution can be defined as "the introduction by man into the environment, of substances or energy liable to cause hazards to human health, harm to living resources and ecological systems, damage to structure of amenity, or interference with legitimate uses of the environment", [5]. Pollutants are therefore chemical, physical or bacteriological in nature and can be measured more or less accurately in water. The physical and chemical characteristics of water determine the quality of water in a particular area [11]. The measured quantities can then be compared with standards of allowable concentrations. Waste is a byproduct of life. High standards of living and ever increasing population have resulted in an increase in the quantity of waste generated [9]. Abattoir wastewater is a typical source of pollution and creates serious environmental concerns, [8]. Abattoir 
operations produce characteristic highly inorganic wastes such as sulphates, phosphates, etc. with relatively high levels of suspended solid, liquid and fat. The solid waste includes condemned meat, undigested food materials, bones, hairs and aborted fetuses. The liquid waste is usually composed of dissolved solids, blood, gut contents, urine and water, [9]. As a result of inadequate waste treatment facilities, wastes from abattoir are deposited on the land or channeled into water resource leading to pollution. Abattoir wastewater has a complex composition and is very harmful to the environment, [6]. It is strong compared to domestic wastewater. It may also contain some manure. Such characteristics render abattoir wastewater treatment very difficult, [2]. The New Artisan River runs through Independence Lay-Out (Phase 2) a major suburb of Enugu urban and other towns in Enugu. It naturally drains the suburbs within its environs. A major abattoir located inside the New Artisan market very close to the bank of the River has all its wastes drained untreated directly into the River. Activities like recreation, domestic and irrigation practices within New Artisan River near the abattoir were impaired because of excessive eutrophication with frequent dumping of untreated animal waste thereby violating standards. There was therefore the need to study the pollution of the New Artisan River by the wastewater from the abattoir. Such study will provide data needed to inform operators of the abattoirs, users of the river and the general public on the level of pollution caused by the discharge of abattoir wastewater into the river. This study will enable stakeholders to carry out assessments aimed at restoration of surface and ground water related ecosystems. It will contribute to sound economic and social development, including poverty reduction through sanitation, wastewater collection, treatment, reuse and reallocation. Therefore, the objective of this study was to determine and measure the influence and pollution level of untreated abattoir wastewater on the physicochemical and bacteriological characteristics of New Artisan River.

\section{MATERIALS AND METHODS}

\subsection{The Study Area}

This study was carried out in an abattoir located very close to the New-Artisan River in New-Artisan, Independence Lay-Out (Phase 2), Enugu, Enugu State, which discharges untreated animal wastewater into the river. About $45 \%$ of the meat (cow, goat and ram) supply to Enugu city is contributed by this abattoir. Cow, goat, and ram are being sold and slaughtered daily. The area taken for study is located between $7^{\circ}$ $29^{\prime} \mathrm{N}$ latitudes and longitude $7^{\circ} 30^{\prime} \mathrm{E}$. In the study area the untreated abattoir wastewater is discharged directly to the river. In order to determine the pollution effects of wastewater from the abattoir on the receiving New-Artisan River, samples were collected from point of discharge. Water is extensively used for washing at all steps of slaughtering and there is no wastewater treatment system at the premises.

\subsection{Methods of Sample Collection and Analysis.}

Samples were collected by grab method from the abattoir and New-Artisan River in Independence LayOut (Phase 2). A grab sample is a discrete sample that is taken at a specific point and time, [1, 7]. Grab samples are collected manually by hand or automatically with a sampler. A grab sample typically is taken by hand with a sampling bottle. The bottle is held just below the surface of the water to avoid contaminants in the surface film. Four liter presterilized transparent bottles with cover were used to collect samples from different points in the river. The collected samples were properly labeled for easy identification.

\subsection{Analyses of Water Samples for Physicochemical and Bacteriological Parameters}

Biological oxygen demand (BOD), Dissolved oxygen (DO), Chemical oxygen demand (COD), Total dissolved solid (TDS), Total suspended solid (TSS), pH, Nitrate $\left(\mathrm{NO}_{3}\right)$, Phosphate $\left(\mathrm{PO}_{4}\right)$, Ammonia $\left(\mathrm{NH}_{3}\right)$, Conductivity, Temperature etc., were analyzed in accordance with the standard methods as contained in [1]. Temperature was measured with a mercury in-glass thermometer in the field; $\mathrm{pH}$ of the samples was determined by using HANNA HI 4212 model pH meter. Total dissolved solids (TDS) were determined using conductivity method. Dissolved oxygen (DO), before and after incubation, was determined by the standardization titrimetric method, Biochemical oxygen demand (BOD) was determined after incubation for 5 days at $20^{\circ} \mathrm{C}$, using standardization titrimetric method at the laboratory. Phosphate was determined using Ascorbic acid method at the laboratory. Conductivity was determined by using JENWAY 470 model conductivity meter immediately after collection. The Chemical oxygen demand (COD) was determined by the Ampule colourimetric method, ammonia by nesslerization method and nitrate by the cadmium reduction method at the laboratory. Total Suspended Solids (TSS) was determined by calculation, using the following formula: TSS $(\mathrm{mg} / \mathrm{l})=T S(\mathrm{mg} / \mathrm{l})$ 
TDS (mg/l). Total solids (TS) were calculated by Gravimetric method while Total Dissolved solids were determined using conductivity meter. Turbidity was determined using Hanna LP 2000 turbidity meter. Total alkalinity was determined using Potentiometric titration. Total hardness was analyzed using EDTA titration; etcetera [1]. All experiments conducted were in line with the American Public Health Association standard methods for the examination of water and wastewater [1].

\section{RESULTS PRESENTATION}

The results as determined and analyzed in the laboratory are listed and summarized in Table 1.

\subsection{Discussion of Results}

Table1, shows the results of analysis of parameters of sources of samples collected from the river near the abattoir in New-Artisan market, Enugu North Local Government Area of Enugu State. The table also shows the comparison of various drinking water standards using the Nigerian Industrial Standard (NIS 554:2007) for drinking water quality and the World Health Organization for drinking water quality. From Table1, the $\mathrm{pH}$ of the sample was 6.54 .

Table 1: Results of Analysis of parameters

\begin{tabular}{|c|c|c|c|c|}
\hline & \multirow{2}{*}{ Method } & \multirow{2}{*}{$\begin{array}{l}\text { Concentrations } \\
\text { in the sample }\end{array}$} & \multicolumn{2}{|c|}{ Drinking water Guideline } \\
\hline & & & NIS 554:2007 & WHO \\
\hline General Appearance & APHA 2110 & & Colourless & Colourless \\
\hline $\mathrm{pH} @ 25.0^{\circ} \mathrm{C}$ & APHA $4500 \mathrm{H}+\mathrm{B}$ & 6.54 & $6.5-8.5$ & $6.5-8.5$ \\
\hline Temperature $\left({ }^{\circ} \mathrm{C}\right)$ & - & 27.6 & Ambient & Ambient \\
\hline Turbidity (NTU) & APHA 2130B & 24 & 5 & 5 \\
\hline TDS (mg/L) & APHA 2510B & 56.7 & 500 & 500 \\
\hline Colour (Pt-Co) & APHA 2120B & 117 & 15 & 15 \\
\hline Conductivity $(\mu \mathrm{S} / \mathrm{cm})$ & APHA 2510B & 113 & 1000 & - \\
\hline TSS (mg/L) & APHA 2540D & 97.3 & - & \\
\hline $\mathrm{TS}(\mathrm{mg} / \mathrm{L})$ & APHA 2540B & 154 & - & \\
\hline Total Hardness & APHA 2340C & 42.0 & 150 & 150 \\
\hline $\begin{array}{l}\mathrm{Ca} \quad \text { Hardness } \quad(\mathrm{mg} \\
\left.\mathrm{CaCO}_{3} / \mathrm{L}\right)\end{array}$ & АРНА 3500-Са В & 26 & - & - \\
\hline $\begin{array}{l}\mathrm{Mg} \quad \text { Hardness } \quad(\mathrm{mg} \\
\left.\mathrm{CaCO}_{3} / \mathrm{L}\right)\end{array}$ & APHA 3500-Mg B & 16.0 & - & - \\
\hline $\begin{array}{l}\text { Total Alkalinity (mg } \\
\left.\mathrm{CaCO}_{3} / \mathrm{L}\right)\end{array}$ & APHA 2320 B & 4.20 & - & - \\
\hline Chloride (mg/L) & APHA $4500-\mathrm{Cl}^{-} \mathrm{B}$ & 10.3 & 250 & 250 \\
\hline Fluoride $(\mathrm{mg} / \mathrm{L})$ & APHA 4500-F- D & BDL & 1.5 & $1.5-3.0$ \\
\hline Nitrate $(\mathrm{mg} / \mathrm{L})$ & - & 17.8 & 50 & 50 \\
\hline Nitrite (mg/L) & APHA $4500-\mathrm{NO}_{2}-\mathrm{B}$ & 0.06 & 0.20 & 0.50 \\
\hline Sulphate $(\mathrm{mg} / \mathrm{L})$ & APHA $4500-\mathrm{SO}_{4}{ }^{2-} \mathrm{E}$ & 8.33 & 100 & 250 \\
\hline Phosphate (mg/L) & APHA 4500-P D & 0.18 & - & - \\
\hline Dissolved Oxygen (mg/L) & APHA 4500-0 G & 8.60 & - & $5.0-9.0$ \\
\hline Calcium (mg/L) & APHA 3500-Сa B & 10.4 & - & - \\
\hline Magnesium (mg/L) & APHA 3500-Mg B & 3.90 & 0.2 & 0.5 \\
\hline Potassium (mg/L) & APHA 3500-K B & 1.70 & - & - \\
\hline Sodium (mg/L) & APHA 3500-Na B & 8.80 & 200 & 200 \\
\hline $\begin{array}{l}\text { Hexavalent } \\
(\mathrm{mg} / \mathrm{L})\end{array}$ & APHA 3500-Cr B & 0.01 & 0.05 & 0.05 \\
\hline Reactive Silica (mg/L) & APHA $3500-\mathrm{SiO}_{2} \mathrm{C}$ & 9.48 & - & - \\
\hline Total Iron (mg/L) & APHA 3500-Fe B & 0.37 & 0.30 & 0.30 \\
\hline Manganese (mg/L) & APHA 3500-Mn & BDL & 0.20 & 0.5 \\
\hline $\mathrm{BOD}(\mathrm{mg} / \mathrm{L})$ & APHA 9220 B & 5009 & & $3.0-6.0$ \\
\hline COD (mg/L) & APHA $9221 \mathrm{~B}$ & 3820 & & - \\
\hline $\begin{array}{l}\text { Total } \\
\text { (cfu/100ml) }\end{array}$ & APHA 9222 B & 9000 & 10 & 10 \\
\hline E-Coli (cfu/100ml) & APHA 9222 B & 7500 & 0 & 0 \\
\hline
\end{tabular}

APHA is American Public Health Association [1], Nigerian Industrial Standard (NIS 554:2007) for Drinking Water Quality. [6], WHO is World Health Organization for Drinking Water Quality [10] and BDL is Below Detection Limit 


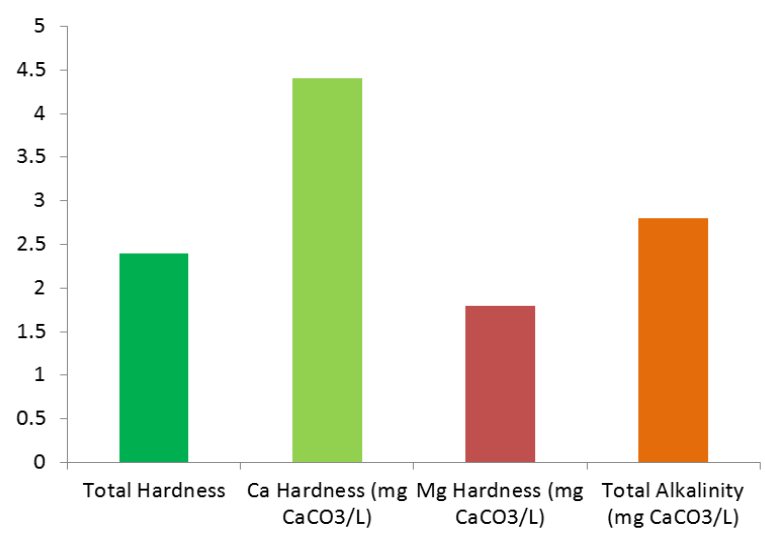

Fig. 1: Changes in Total hardness, Calcium (Ca) hardness,

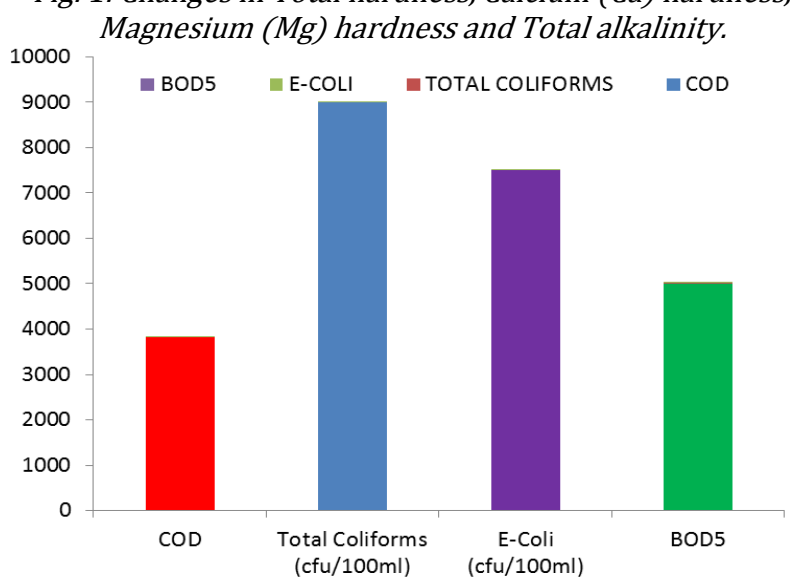

Fig. 2: Changes in Chemical Oxygen Demand (COD), Total coliforms, E-coli and

Biological Oxygen Demand (BOD 5 ).

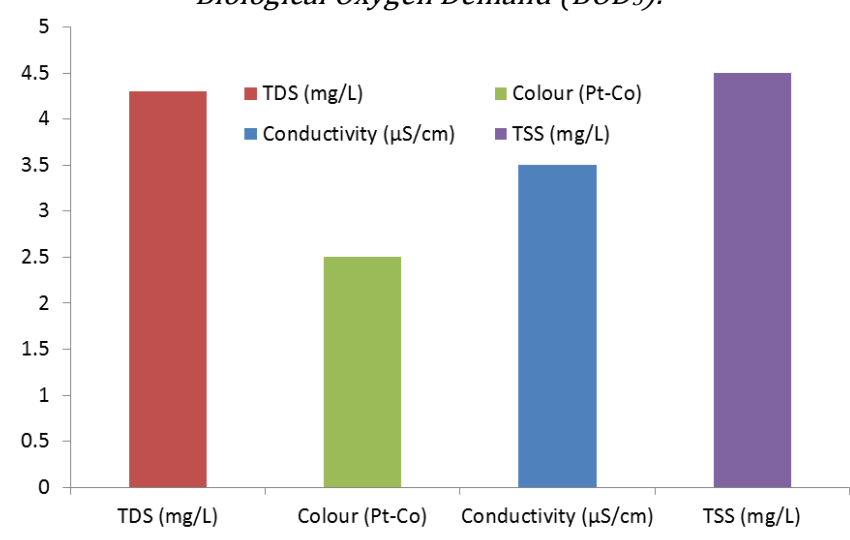

Fig. 3: Changes in Total Dissolve Solids (TDS), Total Suspended Solids (TSS), Colour and Conductivity.

The $\mathrm{pH}$ of the entire sample fell within the stipulated guideline. The role of $\mathrm{pH}$ in water chemistry is associated with corrosives, coagulation, and carbon dioxide stability. Biochemical oxygen demand (BOD) detected in the sample was 5009 (mg/L).The value showed increased BOD indicating pollution of the River. This shows that the high BOD will accelerate bacterial growth in the river and consume the oxygen levels in the river. The oxygen may diminish to levels that are lethal for most fish and many aquatic organisms .Chemical oxygen demand (COD) detected in the sample was $3820(\mathrm{mg} / \mathrm{L})$. The COD obtained fell within the guideline, indicating large amount of organic pollutants entering from the abattoir. Total suspended solid (TSS) detected in the sample was $97.3(\mathrm{mg} / \mathrm{L})$. The value showed increase in TSS indicating pollution in the River. The high level of TSS discharge into the River increases the turbidity of water and causes a long term demand for organic oxygen because of the hydrolysis rate of the organic fraction of the materials. Increase in TSS causes decrease in water body to support a diversity of aquatic life. Suspended solids absorb heat from sunlight, which increase water temperature and subsequently decrease levels of dissolved oxygen. Suspended solids can also harm fish directly by clogging gills, reducing growth rates, lowering resistance to disease, and movement of aquatic population is disrupted, [3]. Total dissolved solids (TDS) values obtained from the sample were $56.7 \mathrm{mg} / \mathrm{L}$. The TDS values obtained fell within the guideline. TDS is used as an indication of the presence of a broad array of chemical contaminants like calcium, phosphate, nitrates, sodium, magnesium, potassium and chloride. High TDS levels indicate hard water, which can cause scale build-up in pipes, valves, and filters, reducing performance and adding to system maintenance costs. TDS is highly toxic with the presence of abnormal $\mathrm{pH}$, high turbidity, or reduced oxygen. Most aquatic organisms tolerate TDS of $1000 \mathrm{mg} / \mathrm{L}$. Conductivity value obtained from the sample was $113 \mu \mathrm{S} / \mathrm{cm}$. The value obtained was below the stipulated value which indicated normal. Conductivity of solution is critically dependent on temperature; the warmer the water, the higher the conductivity. Presence of chloride, phosphate, and nitrate in water raises conductivity. Significant changes in conductivity could then be indications that a discharge or some other source of pollution has entered a River, [3].Temperature values obtained from the sample was $2.76^{\circ} \mathrm{C}$. The values were below the stipulated range, which could have effects on fish and aquatic organisms. Metabolic activity increases with a rise in temperature, thus increasing fish demand for oxygen; however an increase in stream temperature also causes a decrease in dissolved oxygen, limiting the amount of oxygen available to these aquatic organisms. A rise in temperature can also provide conditions for the growth of disease-causing organisms. Dissolved oxygen value of the sample was $8.60 \mathrm{mg} / \mathrm{L}$. The value of the sample was slightly above the stipulated range, indicating that the wastewater could have effects on 
the River. Dissolved oxygen is significant in the protection of aesthetic qualities of water, maintenance of water temperature, the quantity of sediment in the stream, the amount of oxygen taken out of the system by respiring and decaying organisms, and the stream flow, and the amount of oxygen put back into the system by photosynthesizing plants, of any organic materials present, which causes noxious gases, such as corrosion in water pipes. Low DO levels also prevent the detoxification of ammonia. Nitrate values obtained from this work was $17.8(\mathrm{mg} / \mathrm{L})$. The values obtained fell within the stipulated guideline. Nitrate stimulates the growth of plankton and water weeds that provide food for fish and also in crop production as a major ingredient in fertilizer. If algae grow too wildly, oxygen levels, will be reduced to toxic nitrates in the human intestine, many babies have been seriously poisoned by well water containing high levels of nitrate-nitrogen (causing 'blue baby disease'). Phosphate values obtained from this work was $8.33 \mathrm{mg} / \mathrm{L}$. Phosphate stimulates the growth of plankton and water plants and provides food for fish. If too much phosphate is present, algae and water weeds grow wildly, choke the waterways, and use up large amount of oxygen, and other many fish and aquatic organisms may die.

\section{CONCLUSIONS}

From the results presented and their analysis, the following conclusions were made:

i. The $\mathrm{pH}$ of the samples was 6.54. The drinking water guideline show values of $6.5-8.5$ [6], 6.5 8.5 [10], (Table 1). The $\mathrm{pH}$ of the entire sample fell below the guideline.

ii. Biochemical oxygen demand detected in the sample was $5009 \mathrm{mg} / \mathrm{L}$, while the drinking water guidelines show $50.00 \mathrm{mg} / \mathrm{L}$ [6], and $10.00 \mathrm{mg} / \mathrm{L}$ [10]. The values from the sample shows increased BOD indicating pollution in the River.

iii. Chemical oxygen demand detected in the sample $3820 \mathrm{mg} / \mathrm{L}$, while the drinking water guidelines show $100.00 \mathrm{mg} / \mathrm{L}$ [10], (Table 1). The COD obtained is far above indicating large amount of organic pollutants entering from the abattoir.

iv. Total suspended solids (TSS) detected in the sample was $97.3 \mathrm{mg} / \mathrm{L}$, while the drinking water standard is $25 \mathrm{mg} / \mathrm{L}$ [10], (Table 1). The value from the sample showed increase in TSS indicating pollution in the River.

v. Total dissolved solids (TDS) values obtained from the sample were $56.7 \mathrm{mg} / \mathrm{L}$. While the drinking water guidelines show $500 \mathrm{mg} / \mathrm{L}$ [6], $500 \mathrm{mg} / \mathrm{L}$
[10], (Table 1). The TDS values obtained falls below the stipulated guideline.

The outcome of this research shows that the River is polluted and unfit for potable supply. This is as a result of high biochemical oxygen demand which indicates increase in bacterial growth, low oxygen and diminished level of fish and many aquatic insects. The high TSS observed also indicated increase in turbidity causing a decrease in dissolved oxygen which leads to clogging of gills, reduced growth rate of fish. Temperature falls within the range but with increased TSS, the migration of fish will slow down, causing death.

\section{RECOMMENDATIONS}

Given that values obtained for most of the parameters exceeded the guideline stipulated (Table 1), the following recommendation if incorporated will reduce the pollution effects on the River.

i. Construction of wastewater treatment plants for abattoir in the country with a legally enforceable policy framework.

ii. Creation of awareness among the abattoir workers and its environs about the effect and dangers that pollution poses to human and aquatic life, so as to improve health and a balanced ecosystem.

\section{REFERENCES}

[1] APHA, ANWA, WPCF. Standard methods for the examination of water and wastewater. $18^{\text {th }}$ Ed, American Public Health Association, Washington DC. Pp: 18-37. 2005.

[2] Bohdziewicz, J. and Sroka, E. Integrated system of activated sludge reverse. Process Biochemistry; 40; Pp: 1517-1523. 2005.

[3] Chapman, D. Water Quality Assessment. A guide to the use of Biota, Sediments and Water in Environmental Monitoring. Second Edition. E \& FNSpon; London, UK. 1997.

[4] Fewtrell, L. Water, Sanitation and Hygiene Interventions to reduce diarrhea in less developed countries: a systematic review and meta-analysis. Lancet Infect Dis.; 5: Pp: 42-52. 2005.

[5] Mason, C. F. Biology of Fresh water Pollution, $4^{\text {th }}$ ed., Pearson Education, Harlow; Pp: 387.2002.

[6] NIS Nigerian Industrial Standard (NIS 554: 2007) for drinking water quality.2007.

[7] Polprasert, C., Kemmadamrong, P. and Tran, F. T. Anaerobic baffle reactor (ABR) process for treating a slaughter house wastewater. Envir. Technology; 13; Pp: 857-865, 1992.

Vol. 37, No. 1, January 2018 
[8] Ponce, S. L. Water quality monitoring programs. WSDG Tech. Pap.WSDG-TP-0002. Watershed Systems Development Group, U.S. Dept. of Agric., Forest Serv., Fort Collins Co. (www.info.usda.gov/opennonwebcontent.aspx?co $\underline{\text { ntent }}=17843$.wba).1980.

[9] Sangodoyin, A. Y. and Agbawe, O. M. Environmental Study on Surface and Ground Water Pollutants from Abattoir Effluents. Bioresource Technology: 41; Pp; 193-200. Elsevier Science publishers Ltd, Great Britain 1992.
[10] WHO World Health Organization for Drinking Water Quality. 2012.

[11] Onoja, S. B., Isikwue, M. O. and Mallum, J. F., "Physicochemical Characterization of Groundwater of Katungo, Gombe State, Nigeria and Treatment for Flouride Removal", Nigerian Journal of Technology, Vol. 36, No. 2, pp. 655 662, 2017.

[12] Yunana, A. D., Shittu A. A, Ayuba, S, Bassah, E. J. and Joshua W. K., "Climate Change and Lake water Resources in Sub-Saharan Africa: A case study of Lake Chad and Lake Victoria", Nigerian Journal of Technology, Vol. 36, No. 2, pp. 648 - 654, 2017. 